\title{
ESTUdO DE CASO DE GENEALOGIAS DE PORTADORES DO PÉ TORTO IDIOPÁTICO (PTI)
}

\section{TESE}

SILVA, Eduardo Moreira da ${ }^{1}$

COLOMBI, Victor Hugo ${ }^{2}$

SILVA, Eduardo Moreira da. COLOMBI, Victor Hugo. Estudo de caso de genealogias de portadores do pé torto idiopático (PTI). Revista Científica Multidisciplinar Núcleo do Conhecimento. Ano 05, Ed. 11, Vol. 22, pp. 121-134. Novembro de 2020. ISSN: 2448-0959, Link de acesso: https://www.nucleodoconhecimento.com.br/saude/pti

\section{RESUMO}

Este trabalho foi realizado para conhecermos a genealogia dos indivíduos que nasceram com o pé torto congênito (PTC) ou pé torto idiopático (PTI). Trabalhou-se com a ideia de que esta doença é transmitida através de algum gene mutante, ou seja, uma doença genética, sendo transmitida para os descendentes da família. O objetivo foi identificar qual o padrão de herança desse gene mutante nas gerações familiares do indivíduo. Foi realizada uma pesquisa com os indivíduos que nasceram com a doença utilizando-se um questionário padrão para todos os entrevistados, e identificar quais parentescos também apresentaram o fenótipo da patologia. Confirma-se neste sobre a maioria dos indivíduos com pé torto idiopático ser do sexo masculino. A hipótese desse trabalho é justamente baseada nessa diferença da frequência de gêneros nascidos com pé torto congênito, se esta doença estiver ligada ao cromossomo sexual $X$ do tipo recessivo, explica tal diferença. Evidencia-se nos

\footnotetext{
${ }^{1}$ Biólogo.

2 Orientador. Doutorado em Ciências Biológicas. Mestrado em Ciências Biológicas. Graduação em Ciências Biológicas.
} 
resultados que se trata de uma doença genética recessiva ligada ao cromossomo sexual $X$.

Palavras-chave: Pé torto congênito, pé torto idiopático, genealogia, doença genética.

\section{INTRODUÇÃO}

O pé torto congênito é caracterizado por uma ou mais deformidades em um ou em ambos os pés, podendo ser identificadas na prática médica de acordo com a deformidade como: Pé equinovaro (PEV), pé talo-valgo, pé talo-vertical e pé metatarso-varo (SANTIN; HUNGRIA FILHO, 1977). A doença é identificada logo após o nascimento do bebê e alguns casos é possível um pré-diagnóstico no exame de ultra-som. As deformidades envolvem as articulações do tornozelo, subtalar e mesotársica, é aduzido e invertido na região subpatelar. Ainda não se sabe a causa do aparecimento desta doença e nem a forma exata de transmissão.

Apesar do fato de o pé torto ser um dos defeitos congênitos musculoesqueléticos mais comuns, ainda há muito desconhecimento sobre sua etiologia e controvérsias contínuas em relação às melhores estratégias de tratamento. (DOBBS; GURNETT, 2009)

A causa exata do aparecimento do PEV continua indeterminada. À medida que novas informações são obtidas, novas teorias sobre a etiologia são propostas e logo descartadas pelo acúmulo de novos conhecimentos. (SANTIN; HUNGRIA FILHO, 1977, p. 2).

Com etiologia ainda desconhecida, foram propostas várias teorias para explicar a origem do PTC, considerando-se causas intrínsecas ou extrínsecas entre as quais: posição intrauterina do feto, compressão mecânica ou aumento da pressão hidráulica intrauterinas; parada no desenvolvimento fetal; infecções virais; deficiências vasculares; alterações musculares; alterações neurológicas; defeito no desenvolvimento das estruturas ósseas e defeitos genéticos. (MARANHO; AUGUSTO; VOLPON, 2011, p. 3).

Em termos simples, podemos afirmar que quanto maior o número de casos de PEV houver numa família, mais provável o aparecimento de novos e mais graves de PTC. Todavia, até o momento, o mecanismo da transmissão genética permanece objeto de especulação. (SANTIN; HUNGRIA FILHO, 1977, p. 3). 
A maioria das pesquisas realizadas em que o assunto é da doença pé torto congênito, são voltadas para os tipos de tratamentos da doença e a eficácia destes. Durante o levantamento bibliográfico relacionado ao tratamento de PTC, encontrou-se alguns dados que levam a hipótese de como é a transmissão desta doença, mas não sendo possível uma conclusão, pois todas as pesquisas realizadas não abrangem a genealogia do portador da doença e somente métodos de tratamento, esses dados podem ser encontrados nos artigos mencionados na referência bibliográfica deste trabalho.

Um dos dados que se encontra e mostra-se ser o mais importante é a proporção diferenciada dos gêneros nascidos com pé torto congênito, em que a maioria nascidos com PTC é do sexo masculino como citado no trabalho de Santin e Hungria Filho.

O PEV é mais frequente no homem que na mulher numa proporção de 2:1; não se conhece as causas desta diferença. Não há evidência da influência de fatores pré e perinatais no aparecimento do PEV. (SANTIN; HUNGRIA FILHO, 1977, p. 3).

Essa diferença leva à hipótese de que o pé torto idiopático é uma doença genética ligada aos cromossomos sexuais, mais precisamente ligada ao cromossomo $\mathrm{X}$.

A anomalia encontrada com maior frequência neste trabalho foi o pé torto equinovaro congênito, com uma prevalência de 7,2 para 1000 nascidos vivos. A proporção foi de 1,5 do sexo masculino para um feminino. Além disso, o pé torto congênito também foi a anomalia de maior frequência considerando-se o número de todos os três hospitais, predominando no sexo masculino. (PEREIRA et al; 2008, p. 4)

Além disso:

Em termos simples, podemos afirmar que quanto maior o número de casos de PEV houver numa família, mais provável o aparecimento de novos e mais graves de PTC. Todavia, até o momento, o mecanismo da transmissão genética permanece objeto de especulação. (SANTIN; HUNGRIA FILHO, 1977, p. 3).

Diante desses fatos, este trabalho realizou uma pesquisa de campo com os portadores de PTC e com seus familiares para conhecer melhor a genealogia da doença nessas famílias. 


\section{OBJETIVOS}

A principal finalidade deste trabalho foi analisar a genealogia de portadores da doença pé torto congênito (PTC).

Identificar o padrão de herança dessa patologia.

\section{MÉTODOS}

\subsection{PARTICIPANTES E PROCEDIMENTOS EXPERIMENTAIS}

Os participantes do estudo foram indivíduos que nasceram com pé torto congênito maiores de idade ou pais de filhos menores com PTC. Foram realizadas 05 entrevistas e 89 questionários, sendo que $2 \%$ dos participantes tinham doenças neurológicas e não foram considerados, não sendo objeto deste trabalho.

As entrevistas foram realizadas via web conferência, chat online (Messenger, WhatsApp) e pessoalmente. Já o questionário, existia um link que direcionava o participante para a página das perguntas padrão.

Os indivíduos interessados entraram em contato depois de convites feitos em fóruns, no qual os participantes nasceram com pé torto idiopático e de pais de filhos com essa patologia.

Além dos convites, também foi disponibilizado um link para o blogue da pesquisa em questão (https://petortocongenito2.wordpress.com). Nessa página o interessado tinha uma explicação melhor sobre a pesquisa e acesso para responder o questionário caso interessasse e se estivesse no perfil da pesquisa.

O questionário utilizado na pesquisa respondia as seguintes perguntas:

- Gênero do Portador.

- O portador possui alguma doença neurológica?

- Quantos irmãos masculinos o portador possui e quantos deles também nasceram com PTC? 
- Quantos irmãos femininos o portador possui e quantos delas nasceram com PTC?

- Quantos filhos (masculino) o portador possui e quantos desses nasceram com PTC?

- Quantos filhos (feminino) o portador possui e quantos desses nasceram com PTC?

- Quem destes familiares também nasceram com PTC: Pai, mãe, avó paterno, avô paterno, avó materno, avô materno?

\section{RESULTADOS}

Foram realizadas um total de 05 entrevistas e 89 questionários, quanto as entrevistas e aos questionários foram utilizadas as mesmas perguntas, não teve nenhuma ordem cronológica nem hierárquica, todas foram de forma aleatória. Já citado neste trabalho destes 94 participantes, 2\% tinham doença neurológica e não foram considerados para análise dos dados por não se tratar de objeto desta pesquisa.

A pesquisa foi realizada para identificar quais familiares próximos do indivíduo com PTI também teriam nascido com o fenótipo da doença, já que esta deformidade foi tratada nesta pesquisa como causa genética, após a identificação traçar uma linha padrão de transmissão desta patologia.

As tabelas 1 e 2 mostram os resultados da pesquisa.

Tabela 1: Resultado da Pesquisa com os quantitativos, separado por sexo, dos entrevistados que nasceram com a patologia PTC/PTI e também dos seus irmãos e filhos.

\begin{tabular}{|c|c|c|c|c|c|}
\hline & $\begin{array}{l}\text { Gênero do } \\
\text { portador }\end{array}$ & $\begin{array}{ll}\mathrm{N}^{\circ} & \mathrm{de} \\
\text { irmãos } & \end{array}$ & $\begin{array}{l}\mathrm{N}^{\circ} \text { de irmãos } \\
\text { com PTC/PTI }\end{array}$ & $\begin{array}{l}\mathrm{N}^{\circ} \text { de filhos } \\
\text { do portador }\end{array}$ & $\begin{array}{l}\mathrm{N}^{\circ} \text { de } \\
\text { nascidos } \\
\text { PTC/PTI }\end{array}$ \\
\hline Masculino & 64 & 44 & 00 & 01 & 00 \\
\hline Feminino & 28 & 40 & 00 & 03 & 00 \\
\hline
\end{tabular}


Fonte: Compilação do Autor

Tabela 2: Resultado da Pesquisa dos ancestrais dos entrevistados com o fenótipo de PTC/PTI, com os quantitativos, separado por sexo, até os avôs, que apresentam o fenótipo da patologia.

\begin{tabular}{|l|l|l|l|l|l|l|}
\hline $\begin{array}{l}\text { Gênero dos } \\
\text { portadores }\end{array}$ & $\begin{array}{l}\text { Pai com } \\
\text { PTC/PTI }\end{array}$ & $\begin{array}{l}\text { Mãe com } \\
\text { PTC/PTI }\end{array}$ & $\begin{array}{l}\text { Avó paterna } \\
\text { com } \\
\text { PTC/PTI }\end{array}$ & $\begin{array}{l}\text { Avô paterno } \\
\text { com } \\
\text { PTC/PTI }\end{array}$ & $\begin{array}{l}\text { Avó materna } \\
\text { com PTC/PTI }\end{array}$ & $\begin{array}{l}\text { Avô mat } \\
\text { com PTC/ } /\end{array}$ \\
\hline Masculino & 02 & 00 & 01 & 00 & 00 & 01 \\
\hline Feminino & 02 & 00 & 00 & 00 & 00 & 00
\end{tabular}

Fonte: Compilação do Autor

\section{DISCUSSÃO}

Para a análise e discussão dos resultados, interligou-se os dados obtidos para chegar ao objetivo deste trabalho.

A primeira variável analisada foi da frequência do gênero sexual nascidos com o pé torto idiopático.

Tabela 3 - Número de indivíduos, por gênero, nascidos com pé torto congênito.

\begin{tabular}{|l|l|l|}
\hline Gênero & Frequência absoluta & Frequência relativa \\
\hline Masculino & 64 & $70 \%$ \\
\hline Feminino & 28 & $30 \%$ \\
\hline Total & $\mathbf{9 2}$ & $\mathbf{1 0 0} \%$ \\
\hline
\end{tabular}

Fonte: Compilação do Autor

Nota-se que o gênero masculino apresenta a maioria indivíduos nascidos com pé torto idiopático. Como já citado em trabalho anterior, o PTI é mais frequente no homem que na mulher numa proporção de 2:1; não se conhece as causas desta diferença. (SANTIN; HUNGRI FILHO,1977). 
A hipótese desse trabalho é justamente baseada nessa diferença da frequência de gêneros nascidos com pé torto idiopático, uma vez que se essa patologia estiver ligada ao cromossomo sexual $\mathrm{X}$ e for recessiva, explicaria tal diferença. Ao analisar a frequência de qualquer outra doença recessiva ligada ao sexo, observa-se a mesma frequência apresentada na Tabela 3.

O gênero masculino só se diferencia do gênero feminino por apresentar os cromossomos sexuais $\mathrm{X}$ e $\mathrm{Y}$, enquanto o feminino apresenta somente cromossomos $X$. Em uma doença recessiva liga ao cromossomo sexual $X$ basta $o$ homem receber apenas um gene mutante para apresentar o fenótipo da patologia, ao passo que a mulher precisa receber os dois genes mutantes, explicando a maior frequência da patologia em indivíduos do sexo masculino. Assim, conclui-se que os homens só herdam genes do cromossomo $X$ da sua mãe, as mulheres herdam genes do cromossomo $X$ do pai ou da mãe e em casos em que a característica é determinada por gene recessivo, os homens são mais afetados, uma vez que necessitam apenas de um gene para desenvolver a enfermidade (SANTOS, 2018).

Como exemplos de doenças recessivas ligadas ao cromossomo $\mathrm{X}$ temos a hemofilia e o daltonismo. O daltonismo é uma doença que afeta diretamente a percepção das cores. Em um de seus tipos, a doença manifesta-se na incapacidade de diferenciar o vermelho do verde. Assim como no caso da hemofilia, trata-se de uma doença recessiva ligada ao cromossomo $X$ (SANTOS, 2018). Considerando-se os alelos $D$ e d para determinar o daltonismo, temos:

Daltônicos: $X^{d} Y, X^{d} X^{d}$

Portador: $X^{D} X^{d}$

Normais: $X^{D} Y, X^{D} X^{D}$

Comparando com o exemplo do daltonismo e da hemofilia, as probabilidades de os indivíduos do sexo masculino nascerem com estas doenças é de $75 \%$, enquanto a do sexo feminino é de $25 \%$, sustentando os resultados apresentados na Tabela 3 , que apresenta aproximadamente os mesmos resultados. 
As variáveis que ajudaram muito a sustentar a hipótese e a traçar o padrão de herança genética da doença foi o aparecimento do fenótipo do PTC/PTI em alguns membros da família. Ressaltando que, após o tratamento da deformidade é difícil identificar um indivíduo que nasceu com pé torto idiopático, isso faz com que os novos membros da família desconheçam que casos já ocorreram em seus ancestrais, até que ocorra novamente. Por esse fator, acredita-se que uma porcentagem dos participantes respondera de não existência de casos na família por não ter conhecimento de seus ancestrais ou até mesmo por falecimento dos mesmos.

A Tabela 4 apresenta a quantidade de irmãos que os portadores de PTI possuem. Observa-se que nenhum dos irmãos, tanto do gênero masculino e feminino, nasceram com o pé torto idiopático. Vale salientar que mesmo que seja uma doença genética, existe uma probabilidade que o fenótipo da doença não apareça já citado como o exemplo a comparação do Daltonismo.

Tabela 4 - Quantitativo de Irmãos dos Portadores, bem como a incidência que apresentaram o fenótipo de PTC/PTI.

\begin{tabular}{|l|l|l|l|}
\hline Irmãos/Gênero & Frequência absoluta & $\begin{array}{l}\text { Nascidos com } \\
\text { PTC/PTI }\end{array}$ & Frequência relativa \\
\hline MASCULINO & 31 & 00 & $0 \%$ \\
\hline FEMININO & 34 & 00 & $0 \%$ \\
\hline
\end{tabular}

Fonte: Compilação do Autor

Já na Tabela 5 mostra o quantitativo de pais que também nasceram com PTC.

Tabela 5 - Quantitativo de pais que apresentaram o fenótipo de PTC/PTI.

\begin{tabular}{|l|l|l|l|}
\hline Familiar & $\begin{array}{l}\text { Frequência } \\
\text { absoluta }\end{array}$ & $\begin{array}{l}\text { Nascidos } \\
\text { PTC/PTI }\end{array}$ & $\begin{array}{l}\text { Frequência } \\
\text { relativa }\end{array}$ \\
\hline Pai & 92 & 04 & $4,3 \%$ \\
\hline Mãe & 92 & 00 & $0 \%$ \\
\hline
\end{tabular}


Fonte: Compilação do Autor

Dos pais pesquisados apenas o pai apresentou o fenótipo da doença 4,3\%. Já os avós poucos apresentaram o fenótipo da doença como mostra na Tabela 6.

Tabela 6 - Quantitativo de avós que apresentaram o fenótipo de PTC/PTI.

\begin{tabular}{|l|l|l|l|}
\hline Familiar & $\begin{array}{l}\text { Frequência } \\
\text { absoluta }\end{array}$ & $\begin{array}{l}\text { Nascidos } \\
\text { PTC/PTI }\end{array}$ & $\begin{array}{l}\text { com } \\
\text { Frequência } \\
\text { relativa }\end{array}$ \\
\hline $\begin{array}{l}\text { Avó } \\
\text { Materno }\end{array}$ & 92 & 00 & $0 \%$ \\
\hline $\begin{array}{l}\text { Avô } \\
\text { Materno }\end{array}$ & 92 & 01 & $1 \%$ \\
\hline $\begin{array}{l}\text { Avó } \\
\text { Paterno }\end{array}$ & 92 & 01 & $1 \%$ \\
\hline $\begin{array}{l}\text { Avô } \\
\text { Paterno }\end{array}$ & 92 & 00 & $0 \%$ \\
\hline
\end{tabular}

Fonte: Compilação do Autor

Para apresentar melhor uma genealogia da herança genética dessa patologia, foram montados heredogramas para melhor compreensão do padrão de herança do pé torto idiopático. É citado os nomes dos casos, sendo que para preservação dos participantes os nomes são fictícios.

Tabela 7 - Caso específico 1 - Aparecimento do fenótipo de PTC/PTI em mais de um membro da família. Em que o fenótipo aparece em um indivíduo masculino de nome fictício "Pedro" e no seu pai, mas não aparecimento em outros membros da família.

\begin{tabular}{|l|l|l|l|l|l|l|}
\hline Nome & Gênero & Pai & Mãe & Irmã & Irmão & Avós \\
\hline Pedro & Masculino & Sim & Não & Não & Não & Não \\
\hline
\end{tabular}

Fonte: Compilação do Autor 
O caso apresentado na Tabela 7 mostra que a família de Pedro, nascido com o pé torto idiopático, possui 01 irmão e 01 irmã, mas nenhum dos irmãos nasceram com o fenótipo da doença, assim como a mãe e os avós. Já o pai de Pedro apresenta o fenótipo da doença.

Analisando este caso, Pedro tinha $50 \%$ de nascer com a doença assim como seus irmãos. Se o pai possui a doença, certamente ele possui o gene que provoca o PTI, mas se o filho que apresentou a doença é do sexo masculino, com certeza a mãe também possui o gene mutante, mas não apresenta o fenótipo da doença. No caso do irmão que nasceu sem a doença, ele não possui o gene mutante e seus filhos nascerão normais se sua parceira não possuir o gene mutante. Já a irmã possui o gene mutante e pode transmitir para seus descendentes. Observa-se o heredograma a seguir, considerando que $\mathrm{X}$ o é o gene mutante e o X é o gene normal.

Figura 1: Heredograma Caso Específico 1. Nota-se que Pedro e o seu pai apresentaram o fenótipo da patologia, mas como o gene está ligado ao cromossomo sexual $\mathrm{X}$ o heredograma mostra como Pedro veio apresentar o fenótipo da doença através da herança de seus ancestrais, além disso, também mostra o caminho que o gene mutante percorreu e futuro dos seus descendentes de seus irmãos.

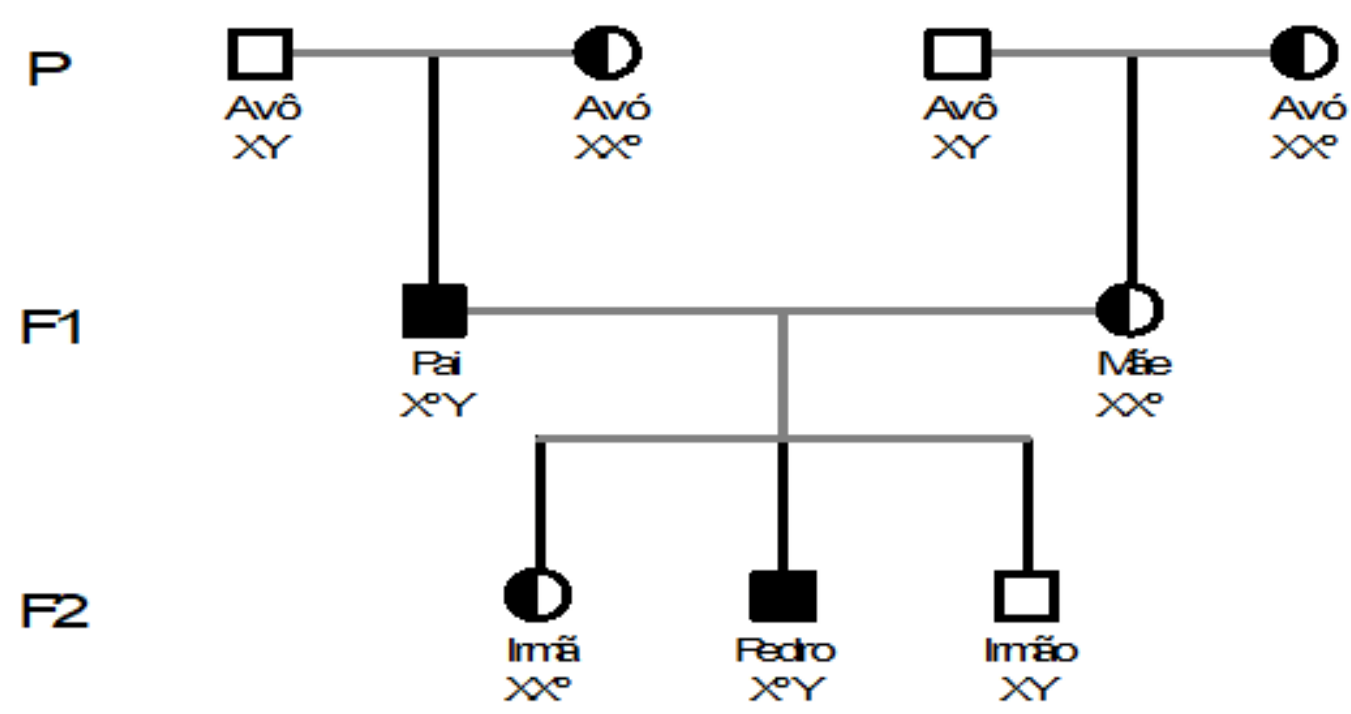

Fonte: Compilação do Autor

Outro caso analisado é o do "Richard", apresentado na Tabela 8. 
Tabela 8 - Caso específico 2 - Aparecimento do fenótipo de PTC/PTI em mais de um membro da família. Em que o fenótipo aparece em um indivíduo masculino de nome fictício "Richard" e no seu avô materno, bem como o não aparecimento em outros membros da família.

\begin{tabular}{|l|l|l|l|l|l|l|}
\hline Nome & Gênero & Pai & Mãe & Irmã & Irmão & Avô M. \\
\hline Richard & Masculino & Não & Não & -- & -- & Sim \\
\hline
\end{tabular}

Fonte: Compilação do Autor

"Richard" nasceu com PTC e seus pais não apresentam o fenótipo da patologia, por enquanto ele não possui irmãos, nem filhos, mas o seu avô materno também nasceu com a condição. Analisando esse caso, nota-se que a mãe de "Richard" não apresenta o fenótipo da doença, mas carrega o gene mutante.

"Richard" possuía $50 \%$ de nascer com a condição do pé idiopático, pois seu pai o transferiu o cromossomo $\mathrm{Y}$ e sua mãe poderia the passar o cromossomo $\mathrm{X}$ normal ou - X mutante. Essa observação podemos notar no heredograma a seguir, considerando que X é o gene mutante e o X é o gene normal. Nota-se que, além do Richard, o seu avô materno apresentou a patologia, mas a sua mãe e suas tias não, apesar de possuírem o gene mutante.

Figura 2: Heredograma Caso Específico 2. É possível observar que além do Richard apresentar o fenótipo do pé torto idiopático (PTI), seu avô materno também apresenta o fenótipo da patologia. O heredograma mostra o caminho que o gene mutante percorreu até o Richard. 
[caption

\section{$\mathrm{P}$}

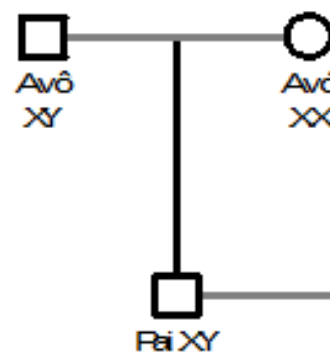

F2

F1

PaiXY
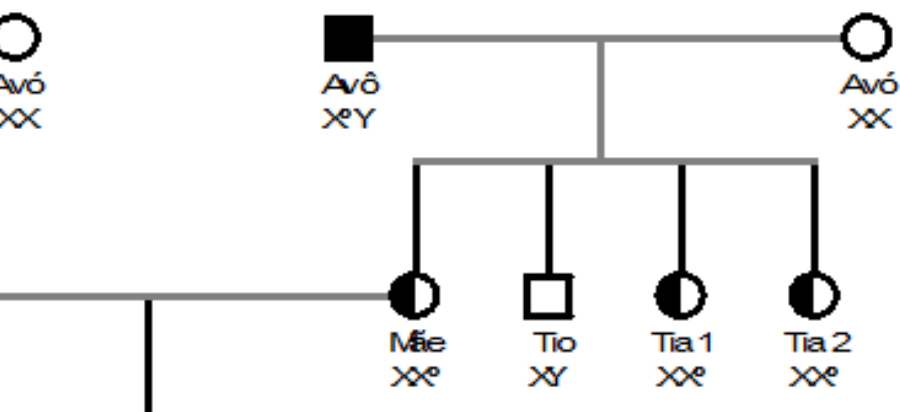

Fonte: Compilação do Autor[/caption]

Apresentando outro caso na tabela 9, dessa fez um participante do sexo feminino.

Tabela 9 - Caso específico 3 - Aparecimento do fenótipo de PTC/PTI em mais de um membro da família. Em que o fenótipo aparece em um indivíduo feminino de nome fictício "Raiana" e no seu pai, e o não aparecimento em outros membros da família.

\begin{tabular}{|l|l|l|l|l|l|l|}
\hline Nome & Gênero & Pai & Mãe & Irmã & Irmão & Avós \\
\hline Raiana & Feminino & Sim & Não & Não & Não & Não \\
\hline
\end{tabular}

Fonte: Compilação do Autor

Analisando a tabela 9. Raiana nasceu com a deformidade do pé torto idiopático. Em sua família além dela, somente o pai apresentou esta deformidade. Sendo que Raiana possui 01 irmão e 01 irmã e nenhum deles apresentaram o fenótipo de PTI, bem como a mãe e os avós.

Como Raiana é do sexo feminino, ela recebeu dois cromossomos $\mathrm{X}$, sendo um de origem do genitor e outro da genitora.

Para que Raiana viesse apresentar o fenótipo da deformidade de PTI, ela precisava receber os dois genes $\mathrm{X}$ mutante. Como seu pai transferiu um deles, provavelmente 
sua mãe também transferiu um gene mutante. Desta forma, Raiana possuía $50 \%$ de apresentar o fenótipo e 50\% de não apresentar, mas carregar o gene mutante assim como sua irmã, podendo herdar para seus descendentes. Já o irmão de Raiana nasceu sem o gene $X$ mutante, ele possuía $50 \%$ de herdá-lo de sua mãe e apresentar o fenótipo.

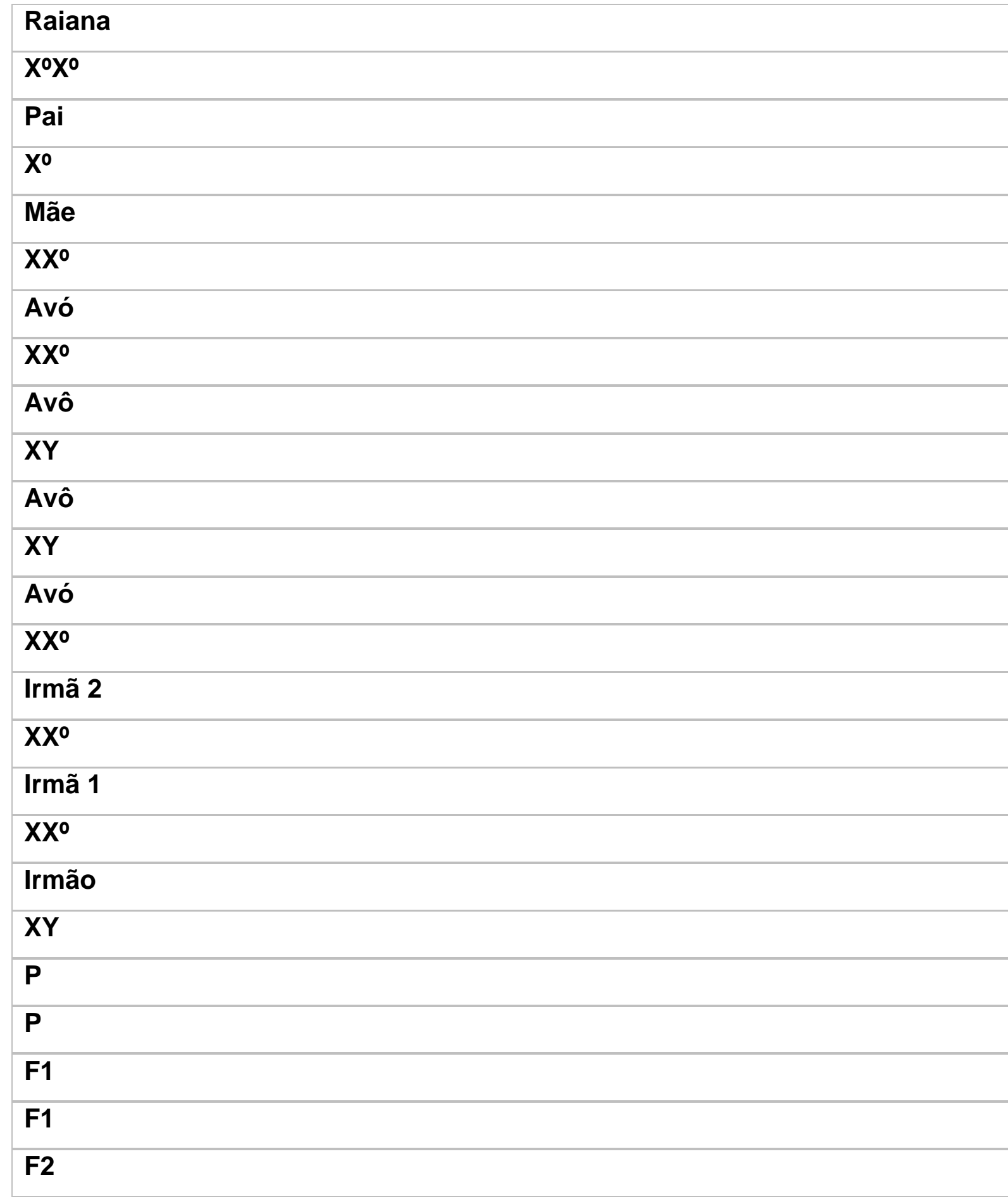


Figura 3: Heredograma Caso Específico 3. É possível observar que além do Raiana apresentar o fenótipo do pé torto idiopático ( $\mathrm{PTI})$, seu pai também apresenta o fenótipo da deformidade. O heredograma mostra o caminho que o gene mutante percorreu até Raiane. Também mostra que suas irmãs não apresentaram o fenótipo da doença, mas possui o gene mutante.

$\mathrm{P}$

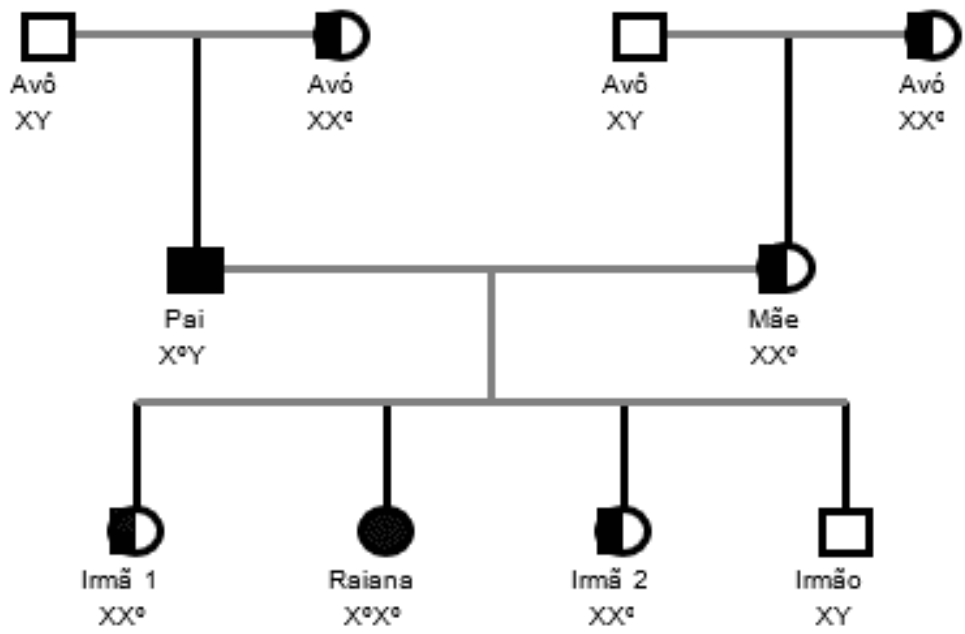

Fonte: Compilação do Autor

Para um melhor entendimento, a figura 03 mostra um heredograma, apresentando detalhamento da análise feita no caso 03 . Considerando que $X \cong$ é o gene mutante e 0 $X$ é o gene normal.

\section{CONCLUSÃO}

Este trabalho realizou um estudo para conhecer melhor a genealogia da doença pé torto idiopático (PTI) em algumas famílias. Corroborando com os dados da literatura, os resultados apresentados aqui mostraram que o PTI/PTC é uma doença genética recessiva que está ligada ao cromossomo sexual X. As condições provocadas por genes recessivos ligados ao cromossomo sexual $X$ não aparecem em todas as gerações, ocorrem poucos casos ou nem aparecem, podendo pular gerações. Além disso, após o tratamento da deformidade é difícil identificar um indivíduo que nasceu 
com o PTI, por este motivo que novos membros da família desconheçam que casos já ocorrera em seus ancestrais, até que ocorra novamente.

Outra evidência é a frequência maior da doença em indivíduos do sexo masculino, elas se comparam com as porcentagens dos trabalhos que tratam de PTI/PTC, além de outras doenças recessivas ligada ao sexo, como a hemofilia e daltonismos.

\section{REFERÊNCIAS}

ABNT - Associação Brasileira de Normas Técnicas. NBR 14724: Informação e documentação. Trabalhos Acadêmicos - Apresentação. Rio de Janeiro: ABNT, 2002.

CORREIA, Amanda Nardi. Diagnóstico Genético Pré-Implantacional. Monografia apresentada como requisito parcial à conclusão do Curso de Especialização em Genética para Professores do Ensino Médio na modalidade de Ensino a Distância. Terra Rica-PR. 2015. Universidade Federal do Paraná.

DOBBS, Matthew B.; GURNETT, Christina A. Update on Clubfoot: Etiology and Treatment. 2009. 2009. Disponível em: <https://www.ncbi.nlm.nih.gov/pmc/articles/PMC2664438/>. Acesso em: 11 jun. 2018. MARANHO, Daniel Augusto Carvalho; VOLPON, José Batista. Pé Torto Congênito. Associação Ortopédica Brasileira. São Paulo, v. 19, pp. 163-169, n. 3, 2011.

PEREIRA, Ricardo Jorge da Silva et al. Frequência De Malformações Congênitas Das Extremidades em Recém-Nascidos. Revista Brasileira Crescimento Desenvolvimento Humano. v.18, p. 155-162, n. 2, 2008.

PIFFERO, Alfeu Cláudio Monteiro. Repercussão funcional da congruência talonavicular no pós-operatório do pé torto congênito idiopático. Programa de pós graduação em medicina, Dissertação de Mestrado. Porto Alegre, 2008. Pontifícia Universidade Católica Do Rio Grande Do Sul Faculdade De Medicina. 
SANTIN, Roberto Attilio Lima; HUNGRIA FILHO, José Soares. Pé Torto Congênito, Clássico publicado na Revista Brasileira de Ortopedia 12: 1-15, 1977. Revista Brasileira de Ortopedia. v. 39, p. 335-356, n.7, 2004.

SANTOS, Vanessa Sardinha dos. "Herança ligada ao cromossomo X"; Brasil Escola. Disponível em <https://brasilescola.uol.com.br/biologia/heranca-do-sexo.htm>. Acesso em 28 de maio de 2018.

SILVA, Monaliza; FELISMINO, Delcio de Castro; DANTAS, Ivan Coelho. Malformações fetais: estudo retrospectivo na maternidade da fundação assistencial da Paraíba no município de Campina Grande. Revista de Biologia e Ciências da Terra, vol. 8, núm. 1, primer semestre, 2008, pp. 232-239, Universidade Estadual da Paraíba, Paraíba.

Enviado: Março, 2020.

Aprovado: Novembro, 2020. 